By PAUL C. REINERT, S. J.

\title{
College and Research Libraries in a Decade of Decision
}

\section{$\mathrm{P}$} RESIDENT EISEnhower's COMmitTeE on Education Beyond the High School has reached six basic conclusions concerning each of which there are certain questions which I think are of peculiar pertinence to those responsible for college and research libraries. The purpose of this paper is to comment on these six conclusions and raise questions suggested by them. ${ }^{1}$

The role of the Committee is to lay before the public the problems of education beyond the high school; to encourage active, systematic attack upon those problems; and to develop, through studies and conferences, proposals to meet those problems. The Committee has thirty-five members, two-thirds of whom are laymen.

To the present the work of the Committee has consisted of meetings as a whole, meetings of its sub-committees, issuance of its First Interim Report (November, 1956), conducting five regional workshops in the fall of 1956 and five regional conferences (attended by fourteen hundred persons) in the spring of 1957. Its second report will appear in August, and state conferences are projected.

\section{Added Structure}

Of first importance is the fact that higher education will greatly revise and

${ }^{1}$ Paper presented at the general meeting of ACRL, June 27, 1957, Kansas City, Missouri.

Father Reinert is president of St. Louis University and a member of the President's Committee on Education Beyond the High School. add to its institutional and organizational structure. This statement is based on the Committee's conclusions that "The needs of the individual and of society plus an unprecedented growth in the population of post-high school age will far outrun the present or planned capacity of existing colleges and universities and other post-high school institutions" and that "The needs of the oncoming millions of individuals with varying capacities and interests will call for a broader range of educational opportunities and less rigid time requirements."2

Changes in existing educational patterns will be required to support this first conclusion. New junior or community colleges, with carefully planned facilities and programs, can help the shortage. Their program may include the first two years of the collegiate curricula, courses varying in time requirements which are needed to integrate general education with vocational-technical training for sub-professional occupations, short courses for upgrading or retraining employees, and adult or continuing-education programs. The establishment of cooperative relationships (along the pattern set by the Southern Regional Education Board) between institutions will be necessary to exploit maximum potential and avoid duplication. There will have to be internal administrative adjustments within the colleges (such as the proposed Oberlin plan) to assure

\footnotetext{
2 President's Committee on Education Beyond the High School, First Interim Report to the President (Washington, D. C., 1956), p. 7. The quotations throughout this paper are from the same source.
} 
greater effective use of time and facilities.

The prospect of such changes raises corollary questions. Will more junior and community colleges result in universities becoming more and more centers of advanced work? If so, book collections will necessarily tend to be built as research collections. Where will four-year liberal arts colleges fit in? Many say they intend to remain unchanged, but many others will expand into graduate and technical fields. Many now have insufficient holdings for advanced work. For example, the collections in teacher training institutions offering the degree of Master in Education too consistently are in need of drastic expansion. What use will education make of such electronic devices as closed-circuit television? Would its use impose more or less of an impact upon libraries? As cooperative relationships spring up, should not libraries avoid the needless expense of building collections in fields not taught at their institution? All available funds will be more directly needed, not only to build in appropriate fields, but also for multiple copies of books to serve greatly increased student bodies. (N.B.: Libraries are already leaders in interinstitutional cooperation: the Farmington Plan for the acquisition of foreign materials; the National Union Catalog for the location of books anywhere in the country; and new experiments such as the Midwest Inter-Library Center.) What new avenues of cooperation can be explored in order to make the nation's book resources freely available? For example, can higher education make more use of our public libraries in meeting the challenge ahead?

\section{NECESSITY FOR RECRUITING}

"Many more able and qualified teachers," states another premise of the Committee, "will be needed than present efforts can provide." This premise leads directly to the conclusion that top priority must be given to the recruitment, training, and retention of excellent teachers. This mounting shortage of excellent teachers is the most critical bottleneck in the expansion and improvement of education. Salaries must be raised and benefits increased. Recruitment must be intensified. Preparation must be expanded and improved. Teacher utilization must be enhanced by giving students more responsibility, by relieving the most competent teachers of tasks others can perform, and by reforming the curriculum, both to reduce its size and to raise its quality.

What the Committee says about college teachers applies with equal, if not greater, emphasis to professionally trained librarians. According to figures I have seen there are today about ten thousand vacancies, and yet only eight hundred are graduating in library science annually. Obviously, librarians have suffered the same disadvantages of inadequate salaries and declining social position as have teachers. In the desperate scramble for the few candidates available, colleges and universities must compete with public libraries, school libraries, government libraries, and libraries in business and industry. Just as some are questioning whether or not accrediting agencies can adhere to the principle that the $\mathrm{Ph} . \mathrm{D}$. degree is the appropriate level of academic achievement for the beginning instructor, so is there dissension over the principle that the M.A. degree must be the minimal professional level for trained librarians.

Is a shorter training period for certain types of positions in libraries possible? Have administrators yet tapped every possible source of assistance and pool of manpower? Can the usefulness of the professional librarian be extended by the placing of more of the routine duties with clerical and sub-professional workers? Can library buildings be 
planned so as to utilize librarians in a more economical manner? Are libraries making full and effective use of automation and its new machines and electronic devices? Can modern methods of promotion be exploited in recruiting for librarianship to arouse greater interest in the importance of librarianship and the satisfactions of a career in it?

\section{OPPORTUNITY FOR QUALITY}

The Committee's report concludes that "Our ideals and the increasing complexity of our civilization require that each individual develop his or her talents to the fullest." The years ahead will provide higher education with unprecedented opportunities for quality.

Though the question of huge numbers of college students presents many a problem, it also presents opportunities. The Committee takes the position that the quantity of students and the quality of education can rise together if the basic educational resources also rise with equal speed. This must be the choice, not of the educators, but of the American people generally. If they are willing to devote a significantly greater proportion of the nation's rising income to higher education, the colleges and universities will not be forced to choose between poorer quality or sharply restricted enrollments. In either of those events hundreds of thousands of able young Americans would be deprived of the opportunity to develop to their full capacities. If forced to choose, the Committee would favor quality as against numbers, for it would do neither the individuals nor the nation any good to masquerade the mass production of mediocrity under the guise of higher education. But the choice between quality and quantity is not mandatory; the nation needs more of both and can have more of both. The public's decision must be expressed in terms of greatly increased income from tuition, fees, private gifts, and tax sup- port for all colleges and universities.

Increased enrollments will enable colleges to introduce the once rejected principle of differentiation. There are many encouraging indications of the death of the long held theory that the recognition of varying capacities is undemocratic. Let me cite a few examples. Both public and parochial elementary schools in St. Louis are introducing ungraded systems. In St. Louis there will be three types of Catholic high schools: (1) major learning program, (2) comprehensive, and (3) prevocational. On the college level, many institutions are introducing honors programs and other special opportunities for the superior student. There is greater acceleration of gifted students out of high school into college.

Will libraries be prepared to provide the wide range of good literature required by such individualized programs, and in sufficient copies? Will the growing tendency toward open-stack libraries, undergraduate reading collections, and other means of readily bringing students and books together be encouraged? Can a greater cooperation between faculty and librarians in promoting use of the library by superior students be obtained so that the students can realize maximum value from their opportunities.

\section{EDUCATION FOR LEISURE}

Our technological age demands education for leisure. The fantastic advances of which the human mind is capable seem endless in their future potential. It would seem certain that with automation moving forward, most Americans will be working shorter hours and fewer days per week. The substantial part of a man's or woman's life will no longer be completely taken up by working, eating, and sleeping. Here, again, change provides education not only with an unprecedented opportunity but with a new obligation. If we do not educate our 
young people for leisure, we will be contributing directly to the alarming spread of delinquency, the breakdown of home life, the horrible disintegration and waste that comes with long and constant pursuit of cheap entertainment and unhealthy pleasures. Here, again, it would seem to me, is a most fertile field for your endeavors.

Can you librarians accelerate the flight from cheap TV programs and other forms of entertainment by engendering in our young people an abiding appreciation of books, art, music, and all those creative activities which blend the best we can offer in the formation of mind and heart with wholesome forms of human pleasure and enjoyment?

It has often been expressed that the role of the public library is to provide for the continuing education of our citizens after their formal education is completed. Can and will the college and university librarians encourage in students an abiding desire to continue the use of libraries after graduation? The President's Committee points out that there are four major educational systems in operation: the traditional system of schools and colleges, an elaborate educational program under the military, a mushrooming system of education operated by private business, and a great variety of programs of continuing education generally grouped under the heading "adult education." One of every three adults, an estimated fifty million, participate in some form of adult education program. What part are librarians playing in efforts to coordinate and improve these programs, to prevent overlap and duplication, to bring some sort of ordered system into the growing but amorphous field called "adult education"?

SOURCES OF SUPPORT

Higher education must find newer and greater sources of financial support. "Even with the best possible utilization of existing resources," declares the Committee, "additional financial support must be provided if the additional millions in the population are to be enabled to develop their talents to the fullest."

Some resolution must be found to the present inconsistency in the methods of meeting the costs of higher education in the United States. Here is an appropriate place to commend the Association of College and Research Libraries for its splendid work in obtaining grants to help liberal arts college libraries from the U. S. Steel Foundation, the Sperry Rand Corporation, the Lilly Endowment, and others.

There are two extreme positions. The first asserts that society should pay the total costs, that the citizenry as a group should subsidize higher education. Why? Each citizen has a right to an education; society needs trained manpower to survive and prosper. There are disadvantages in this position: to the student there is the psychological deterrent of the "hand-out," loss of initiative, lack of a sense of values of working for a goal, lack of a sense of personal investment; to society there is loss through the attitude that services can be judged in value on the basis of costs assessed (education today has a low priority as a social value because it is comparatively cheap); to private education there is loss in the fierce competitive element produced by the cost differential which demands that almost fifty per cent of operating income be secured from other sources than direct payment and which results in penalizing the teaching profession by forcing it to subsidize education by foregoing higher salaries.

The position of the other extreme asserts that the individual and his family should pay total costs. Why? Education is a responsibility of the individual and the parents, not a right but an opportunity. Since it promotes initiative, places a high priority value on education, and tends to place private education on a 
competitive basis with public education, this position does not have some of the disadvantages of the other. Nevertheless, it has other disadvantages. As long as tax-supported education does not increase the direct cost to an individual student, the imbalance between total enrollments in each type of institution will increase. Payment of total costs places too heavy a burden on many individuals and families and thus discriminates against those of modest means. It might in time price private education out of business.

The correct answer to the problem of financing higher education must lie somewhere between these two extremes. One thing is certain. Colleges and universities will require in the next ten years an enormous expansion of funds from all customary sources: tuition and endowment income; gifts from alumni, corporations, and other private donors; and subsidies from state and local governments.

In order to secure more nearly adequate salaries for our faculties, including librarians, should not private institutions consider charging full or nearly full cost in tuition? If this were done, could not students of limited means be taken care of by deferred payments, extended loans, or pay-as-you-earn plans? Would not foundations and corporations be sympathetic enough toward such a sound financial system that they would be interested in contributing to higher education by providing revolving funds to assist institutions during a transitional period until the new system was in full operation? Is it commendable that there is some tendency among state legislatures to urge higher tuition rates in taxsupported institutions in order that the individual bear a higher proportion of the cost of his education?

\section{Role of GovernMent}

There emerges the necessity of the formulation of policy on the role of the
Federal Government in higher education. As the President's Committee states it, "There must be promptly formulated an explicit, considered policy as to the role of the Federal Government in education beyond the high school." Historically, the Federal Government has supported education beyond the high school in many ways: through land-grant colleges, through military programs, through the "G. I. Bill," and through research. Thus far, such aid has largely been on an ad hoc basis, in response to some pressing need. Currently there are two widely divergent positions, each vigorously upheld. On one hand it is averred that any type of Federal aid will lead to Federal control and should be opposed; on the other, that Federal aid alone can solve our national educational problems.

The President's Committee emphasizes that there are many ways in which the Federal Government can and should discharge its responsibility to higher education which do not involve financial aid. For example, the Office of Education in the Department of Health, Education and Welfare could be greatly improved as a clearing-house of accurate, current information, as a source of stimulation of research in problems of higher education, and as a source of assistance to the various states in their badly needed, long-range educational planning.

\section{Financial Support}

As far as actual financial support is concerned, the Committee favors the continuance and extension of the programs in which the Federal Government is now engaged, e. g., the College Housing Loan Program, with its low rate of interest; use of the slum-clearance provisions of the National Housing Act to assist urban institutions in the acquisition of land needed for expansion; a new program comparable to the HillBurton hospital program to assist public and private institutions in the construction of non-income-producing facilities 
such as classroom, laboratory, library, and administration buildings; payment of full costs, including the indirect costs to institutions, for ROTC programs, research projects, and so on; encouragement of larger contributions from more individuals through revisions of Federal revenue laws.

If all other sources of financing higher education prove inadequate, which forms of Federal assistance should faculties and administrations of higher education prefer? Should we prefer assistance to the individual, such as tax credit plans which help parents; scholarships; loans; or a work-study plan comparable to the program of the NYA in the 1930's? A recent survey of American institutions indicates that a vast majority favors a Federal scholarship program if some form of aid is definitely to be given. But loans find some favor. A work-study program also finds favorable, but not as wide, support, though some members of the President's Committee strongly prefer such a program over either scholarships or loans. Or should we prefer assistance to the institution? This would be in the form of grants for research, loans or grants for housing and other self-liquidating facilities, and loans or grants for other educational facilities.

If Federal aid is to come, would it not be wise for college and university faculties and administrations to support scholarships, loans, and work-study programs? Such programs, through aiding the individual directly, avoid the inevitable difficulties of the problem of church-state relationships. They may help avert the disturbing tendency of many corporations, especially those national in scope, to contribute to higher education only through scholarship programs, as a method of avoiding a choice between institutions. It is important to emphasize here that scholarship assistance, from any source, even when it be accompanied by a cost-of-education bonus to an institution, is not aid in any- thing like the true sense in which contributions directly to an institution for either operating or capital expenditures are aid.

Summary

Higher education will greatly revise and add to its institutional and organizational structure. Librarians must be alert and willing to adapt to these inevitable changes.

Top priority must be given to the recruitment, training, and retention of excellent teachers. Librarians, as essential members of faculties, must examine their current training programs with a view to increasing the attractiveness and efficiency of librarianship as a career.

The years ahead will provide unprecedented opportunities for quality. Increased holdings by libraries and increased service by librarians are essential to any program seeking the goal of quality.

Our technological age demands education for leisure. Librarians must share the responsibilities imposed by this demand and exert efforts far beyond their present commendable accomplishments.

Higher education must find new and greater sources of financial support. Librarians must share in this responsibility and exert efforts far beyond their present commendable accomplishments.

A defensible policy on the role of the Federal Government in higher education must be formulated. Here, again, as vitally interested parties, individual librarians and this Association should develop a consistent policy and exert every effort to ensure its wide consideration.

\section{ConcLusion}

I had intended to conclude with a few observations as to what information such a group as this might furnish the President's Committee in its continuing deliberations. However, an economy-minded Congress will probably curtail the plans of the Committee as originally 
formulated. In other words, most of the appropriation to the Committee still available will have to be used in publishing the materials already in preparation. Therefore, there are only two concrete suggestions I can make in this connection. First, become acquainted with, and be sure your libraries secure as soon as they appear, the second report of the Committee, which is now at the Government Printing Office; the reports of the five regional conferences; a source book which will contain valuable data on projected enrollments, educational costs, and so on; and a case book which will highlight in concrete terms some of the more pressing problems of higher education. Second, encourage, and, if possible, participate in, state conferences which are already being planned in some states. The Committee will do all it can to stimulate the holding of such conferences even though it is quite certain that the several states will have to finance these conferences through their own resources.

\section{Personal Observations}

Let me finish with three personal observations typical of a university president who is primarily occupied with fund-raising and endeavoring to meet all the demands for added financial help coming to him from every school and department of his institution.

The library as the very heart of an institution, as the element in education second in importance only to the faculty is a concept which is extremely hard to sell to the general public. I am acutely aware of this from my present efforts to raise four million dollars for the Pius XII Memorial Library now un- der construction in St. Louis. All your ingenuity must be directed toward increasing the public's understanding of the role libraries play in the educational process, if the support we need is to be forthcoming.

Within institutions themselves - with the press of numbers, with the inevitable tendency to give in to a passive, "fillingstation" type of education with too much emphasis on television and mass consumption-the importance of books may be more and more difficult to promote. Hence, you must be eternally vigilant, not as an organized pressure group nor as lobbyists (university presidents tend to resist such efforts), but through positive promotion based on excellent, intelligent service supported and appreciated by the strong, key members of the faculty, particularly the deans and directors of departments. Dedicated service to faculty and students is the best guarantee that your pleas for financial assistance to meet greater demands will fall on the sympathetic ears of those who control budgetary policy.

All of us must resist the appealing emphasis on things in higher educationbuildings, facilities, equipment (including library buildings) - to the neglect of what is far more important, persons, whether they are serving in the classroom, laboratory, or, as in your cases, the library. Unless we keep a proper sense of values and true perspectives, our rapidly expanding colleges and universities can become magnificent mausoleums, filled with dead men's bones, instead of citadels of learning where a community of living scholars is actively engaged in the preservation, discovery, and teaching of the wisdom of the ages. 